\title{
The possibility of the application of sustainable development strategies in agricultural projects.
}

\author{
Soran Hama Saeed Hama Salih+ \\ Management science, College of Commerce, University of Sulaimani
}

\begin{abstract}
In my project start with a discussion of the greenhouse tomato and cucumber industries in Kurdistansulaimanyacity as example of my project. Noting each country's fresh tomato trade profile. In addition to describing of my project on the evolution of the Kurdistan - sulaymani city greenhouse tomato industry, greenhouse tomato and cucumber market, in this project contantfoure chapter in the principal consumer market in Our fields and the strategic of my study. Following is chapter one Tomato \& cucumber greenhouse business, chapter tow: Green house product cost and return computation, chapter three: marketing greenhouses and financial statementchapter,. Greenhouses in Kurdistan and Economically analyses Daily prices by type of greenhouse tomato and cucumber are available on imports from market in Kurdistan. The findings of this reportreflect the use of all available public information, supplemented by extensive primary datacollection from industry sources.
\end{abstract}

Keywords: Greenhouse, tomato \& cucumber's, growers in the Kurdistan, strategic of sustainable development of agriculture product.

\section{Introduction}

Competitiveness deals In greenhouses in the fact with the question: 'Who is the best in meeting the consumers' and discuss preferences?' The company with this idea success factor will provide the consumers with products tomato and cucumber. This looks like a simply question about project; however the answer is complicated the Cassese. I thought billions of consumers decide daily which produce they buy and where is the market please to competitiveness. Their buying decisions depend on several aspects like sutable of the produce tody in the real market, the price of the product greenhouses or their flavor.(Rob Eddy,2001,p21) Competitiveness can be dealt with from different viewpoints we descuss in this project. The key success factor is fulfilling the consumers' preferences by new varieties of the product, a differentiating assortment or exclusive concepts of the financial situation. The achievement of company in combining the resources in such a manner that their products are distinctive or that the price is lower than the competitors is the central point. It is obvious that a lot of greenhouses are involved in providing the consumers with goods. The horticultural for instance consists of plant breeders, growers, marketing , advertising.Rob Eddy,2011,p.21)

As recently as the early 2007, greenhouse project in Kurdistan tomatoes and cucumber were a specialty Product and most came from the village near the city that were build. Greenhouse tomatoes were being allotted sizable shelf-space in most field. The greenhouse project is large enough to impact company for all fresh tomato and cucumber growers. This report documents the emergence of the sulaimanycity about greenhouse tomato industry and assesses its impact on the fresh tomato sector ( Maria I.. Marrsh,2001,p.11).In my project I start with a discussion of the greenhouse tomato and cucumber industries in Kurdistan-sulaimanyacity as example of my project . Noting each country's fresh tomato trade profile. In addition to describing of my project on the evolution of the Kurdistan - sulaymani city greenhouse tomato industry, greenhouse tomato and cucumber market, in this project contentfour chapter in the principal consumer market in Our fields and the strategic of my study(Rob Eddy,2011,p21)

Following is chapter one Tomato \& cucumber greenhouse business, chapter tow: Green house product cost and return computation, chapter three: marketing greenhouses and financial statementChapter,. Greenhouses in Kurdistan and Economically analyses. (greenhouse co., 2001, p20)

Daily prices by type of greenhouse tomato and cucumber are available on imports from market in Kurdistan . The findings of this report reflect the use of all available public information, supplemented by extensive primary data collection from industry sources. provide monthly unit-value border prices for imports on all imported greenhouse tomatoes, by country of origin, but no information on price by type orsize of greenhouse that I talk in sulaymanyha city zone for greenhouse.Objectives of the Study

The major objectives of the study were :

1-Determination of the structure of the greenhouse industry in sulaimani that we receive ten place. And estimate my project building greenhouse in tanjaro places

2-Estimation of greenhouse production costs and increases the number of greenhouse . 
3-Identification of the main factors influencing production and marketing of greenhouse as new project in sulaimani city .

4-Identification of major problems experienced by greenhouse producers in Kurdistan -sulaimani.

5-Economically how the project effect on the environment and increase the local product with suitable prices .

\section{Literature Review}

Can be divided into open field and greenhouses In KURDISTAN Suleiman city and protected agriculture by the farmer, Wide category of production Protected agriculture the way to providing some grade of control over various environmental factor from disease. Cost of the house start with simple shade-house structures and ending with high technical greenhouse cucumbers tomato and. Growers have many choices with respect to the kinds of structure to protect their production in the fields and kind of product; the degree of environmental can be control to adopt within the structure of the house that provides passive control by shading the plants tomato and cucumber from excessive sunlight and wind. Greenhouse plastic tomato and cucumber production has come serious industry regarding tomatoes produced with any type of protected agriculture then can be labeled as greenhouse. Can be grown in (a fixed steel structure can be using irrigation and environment have control, an artificial medium that substitutes for soil) we means that tomatoes labeled as greenhouse and marketed in Kurdistan must be grown best quality( Rob Eddy, 2001, p20)

In this project, we protected agriculture into two broad categories: shade house and greenhouse, the latter not limited to hydroponics but requiring a fixed, permanent structure. There is a range of greenhouse technologies that have been loosely defined as low-, medium-, and high-technology greenhouses. We can be defining a low-technology greenhouse as involving only a fixed, permanent structure with limited or passive environmental control. A medium technology system involves greater environmental control and/or the addition of hydroponics. A high-technical system requires both fully active environmental contro. (Manuel Paucar,2003) Development and increase the fresh of new types of tomatoes and cucumber in the sulaimanicity is faster for greenhouse production than the open field production, which allows greenhouse growers more opportunity to target growing consumer to interest in variety The main producers of a popular new tomato and cucumber product can garner substantial profits, at least for a few years. The popular tomato-on-the-vine (TOV), or cluster tomato, is only grown in greenhouses, which gives greenhouse Producers a competitive product(greenhouse co., 2001, p20)

Generally Greenhouse tomatoes have better appearance and redder in color than field tomatoes ; but actually some field tomatoes and cucumber may be just as attractive to many consumers to buy it. Now some consumers seem to perceive greenhouse tomatoesHaving superior flavor to field grown tomatoes; however, flavor is a subjective attribute and not all consumers agree. can vary substantially depending On varieties, seasons, maturity level, handling practices, and time in the distribution system, for the field and greenhouse tomatoes(Roberta Cook and Linda Calvin, 2001, p20)

Most recognized important may be greenhouse tomato grower as a great point of differentiation, including favorite, really more easily be maintained in climate-controlled greenhouse production than the other open field product conditionsGrown Greenhouse tomatoes\& cucumber with few if any pesticides, then more field tomatoes are too grown with integrated pest management analyses techniques and some are certified to be pesticide-residue-free. Greenhouse tomatoes and cucumber are exposed to fewer environmental hazards than open-field tomatoes and cucumber, reducing the chance of microbial contamination (Manuel Paucar,2003)

Between greenhouse and field tomatoes and cucumber it is not always clear whether most consumers can distinguish them, retail buyers are probably more interested in the differences greenhouse . Most greenhouse tomatoes are sold in retail markets, which represent about half of tomato consumption. Greater consistency than field growers in Greenhouse tomato growers provide .( George Hochmuth,2001,p.60).

\subsubsection{Greenhouse Tomatoes \& Cucumber background of the Kurdistan fresh tomato industry}

The rapid growth of the Kurdistan greenhouse tomato industry has changed the longstanding of the fresh tomato industry. During the10years ago , Kurdistan emerged as the largest producer of greenhouse tomatoes, a prominence it never attained in the fresh field tomato and cucumber industry. The United States and Mexico have also become important greenhouse tomato producers. Greenhouse tomatoes and cucumber have changed the look of U.S. retail tomato sales, where they now account for 37 percent of the quantity sold of fresh tomatoes. Mature green tomato in our country industry is now very dependent on the continuing(Nabi Chaudhary,2011,p53)

Growth of the food service market, which generally prefers its product .The Kurdistan greenhouse tomato industry has grown rapidly since the early 2000 and now plays a major role in the fresh tomato industry.

However, relatively little is known about this new fields industry, in another part because of the lack of reliable production greenhouses, trade, and price information data. Both analysts and industry benefit from a 
more comprehensive understanding of the rising greenhouse industry and its effect on the entire fresh field tomato sector.(Manuel Paucar,2003).

\subsubsection{What Type of Business Green Houses Will I want Establish?}

In my opinion consideration in starting a greenhouse projectBusiness is to decide how the business should be structured. Usually, the business is structured in one of three methods: sole proprietorship, partnership, or corporation. Each legal structure has several advantages and disadvantages. Consult an CAN BE accountant to decide on the structure that best suits your needs. Most entrepreneurs start, sole proprietorship legal form of business. The primary advantage..( James Rada,2011,p.43)

of this form of business is that, the sole proprietor, are responsible for the assets and liabilities of the business. In my our project (greenhouse project ) are the boss. Company have complete liability, and they are taxed personally for the profits of the business and loss of profit . However, your personal and business assets can be taken awayif the business has financial trouble and company owescreditors money(Nabi Chaudhary,2011,p.55). The third form of typr of business stricture is corporation. Today, greener house businesses are corporations because of the advantages a corporation offers and my project related to this type. Unlike the sole proprietorship and partnership, the corporation is only liable when times. Good sources of extra, part-time help are high school students or older, retired adults. Labor should be available at a price you can afford by green house project(Manuel Paucar,2003). Water quality and availability. Is city water available or will you have to dig a well? If you dig a well, how much water is available and how long will it last? Many greenhouses require about 6 acre-feet of water per year for every acre of greenhouse production area. Regardless of the source, have a water quality testperformed. This is an inexpensive, easy procedure that may save a lot of money in the future. Company will also need a plan for water collectionand a plan for water runoff from your greenhouse project . (NabiChaudhary, 2011,p.56).

(1)Utilities. How many are available for the project with out hesitations, and what are the connection fees for green house? You will need electricity and, depending on other equipment and needs, may need gas, water, or sewer services connected. Check with each supplier to determine costs and to anticipate any difficulties they might have in supplying services(2)Taxes. What is the tax rate on the property?Are taxes likely to increase substantially in the future forcing you to move the business elsewhere? In my project as a table ( (3)Local building codes. What codes will affect which buildings company construct and where on the property you locate them ?(5)Neighboring businesses. What affect will other businesses have on traffic flow of customers into and out of your business? In Kurdistan product come from three border ( iran - syrya - turkey) (6)Natural slope and drainage of the land.(James Rada,2011,p.53). Grading land can be very expensive for the company to istablish the project. Greenhouse structures should be located on a slope of 5 percentor less. Avoid locating a greenhouse on a flood plain, in a frost pocket, or on a hilltop where heating costs will be high. Avoid an area where nearby structures or trees will cast shadows on the greenhouses .(7)Resale value. Someday it should be necessary to sell the property, For good or bad reasons, so have an estimate of its resale value in the future.( James Rada,2011,p54).

\subsubsection{Operational management Greenhouse Production}

Computation of Individual Cost Components

[1]Interest on Investmentoperational management divided in three general plan namely,perproduct,post production . Interest of the project is defined as a sum paid or calculated for the use of capital of the greenhouse production. The sum is usually expressed in terms of a rate or percentage of the capital involved, called the interest rate. Interest is charged for the use of investment capital. The capital had not been invested to buy a specific asset;( Efren fitz,Rodreguez,2008,p15). it could have been used elsewhere for the project, either within or outside the firm and would have brought some additional return to the firm. Also, for the aims of this study, indeed paid capital interest was used to arrive at capital costs .[2]DepreciationDepreciation in our project is defined as the loss in value of an asset and goods over time, basically as a result of obsolescence. In the case of buildings the house and equipment, it is that portion of the decrease in value resulting from the passage of time. Obviously, part of the reduced value of the buildings and equipment is the result of usage and is considered a variable cost(George Hochmuth,2001,p.62). The entire depreciation is considered a fixed cost .In computing depreciation, a 10 percent allowance or salvage value is taken from the purchase price of the buildings and equipment. The following formula was used in arriving at depreciation for buildings and equipment(Efren fitz,Rodreguez,2008,p15).

Depreciation $=$ Purchase Price - Salvage Value

Number of Years of Lif

[3]Land ValueLand associate with each greenhouse operation activity was valued at $\$ 5,500$ per acre, irrespective of its place. This value was determined through real estate values for good farmland suitable for a greenhouse operation. (Allen Straw, 2000, p.60).. Researchers are aware that land values in cities or towns are 
much higher than $\$ 5,500$ per acre, but if market price were used for land acquired seven years ago, it would lead to artificially much higher fixed costs that would greatly inflate overall production costs.[4].Property and Business Taxes on the project greenhouse real estate including payments made on the assessed value of the greenhouse operation less any assessment for the greenhouse tax of employee or operations other than the greenhouse. [5\}Labour Costs :Labours costs included the amount of wages and any benefits received by the tomato sales, such as contributions to Workers' Compensation, sulaimani Pension Plan, and Unemployment Insurance. (Allen Hammer2011,p.2) .[6]Materials and Supplies ProductionMaterials and supplies Production included the purchase of (cuttings- seed plants- fertilizers- chemicals- soils, vermiculite- perlite- peat mossstraw- peat pots and plastic(Efren fitz,2008,p.15). [7]Costs of heatingMajority of greenhouse tomato and cucamber operators had reasonably accurate costs for heating the greenhouses with natural gas. (Allen Straw, 2000, p.65). [8]Utility costs included electricity, telephone and water another cost. Where the utility bill was combined with the greenhouse operator's residence, the operator was asked to apportion the bill to arrive at total utility costs for the greenhouse operation (cucumber \& tomato-[9]Transportation ExpenseExpenses for trucks or other vehicles owned by greenhouse operators were apportioned according to their use in the greenhouse operation, personal and leisure driving(employee salary,rent,engnear tax(Efren fitz,2008,p.15). . In my greenhouses show the transportation are deferent in the place to another place in Kurdistan the Freight charges paid to commercial or private carriers for hauling greenhouse produce or supplies were included in the transportation expenses(Allen Straw, 2000, p.65).[10]Low Cost Green Houses for Vegetable ProductionOur experience has demonstrated the strong and main correlation between agricultural growth and economic prosperity. (Douglas Street, Victoria, 2008, p.38). human has learnt how to grow plants under natural environmental conditions.(Allen Hammer2011,p.2) some of the temperate regions where the climatic conditions are extremely adverse and no crops can be grown, man has developed ways of growing some high value crop continuous by providing protection from the excessive cold,(William A. Thomas,2011,p.21) which is called as (Greenhouse Technology.So, Greenhouse production new Technology is the technique of providing favorable environmental condition to the plants. It is used to protect the plants from the adverse climatic conditions such as wind high temperatures, cold, precipitation, excessive radiation, extreme temperature, insects and diseases cause. It is vital importance to create an ideal micro climate around the plants. This is possible by erecting a greenhouse / glass house, where the environmental conditions are so Modified, that one can grow any product in any place at any time by providing suitable environmental conditions with minimum labor(Allen Hammer, 2011, p.3).

.(Kurdistan, 2011, p52). Financial report ofgreenhouse company : Each greenhouse need to have the capital to bulding green housese in Kurdistan we need(john allen ,2011,p.23). Greenhouse framing takes second billing to the material used as siding, but an unsuitable frame material can mean and unsteady frame that will never really be square.(Allen Hammer2011,p.6) Aside from the headache that will give you with assembly, it will also result in drafts and openings for pests and critters. Many times you don't get a choice of framing, but here are some considerations while you are shopping around for a greenhouse.(sulaimani,for bulling greenhouse,2011,p3).

Table1: The costs in the rest of the sulaimani

\begin{tabular}{|l||l||}
\hline \multicolumn{2}{|l|}{$\begin{array}{l}\text { The costs in the rest of the sulaimani are shown in table. It is shown that the profit margin is rather } \\
\text { small. } \%\end{array}$} \\
\hline \hline Growers & $\$ 21,0$ \\
\hline \hline Labor & $\$ 38,5$ \\
\hline \hline Packaging & $\$ 8,5$ \\
\hline \hline Transport & $\$ 4,0$ \\
\hline \hline Deprecation & $\$ 3,5$ \\
\hline \hline Advertisements & $\$ 4,0$ \\
\hline \hline Energy & $\$ 3,5$ \\
\hline \hline Rent and other costs & $\$ 13,5$ \\
\hline \hline $\begin{array}{l}\text { Profit } \\
\text { (total chain exclusive growers) }\end{array}$ & $\$ 3,5$ \\
\hline \hline Total & 100,0 \\
\hline
\end{tabular}


The possibility of the application of sustainable development strategies in agricultural projects.

\subsubsection{Business and marketing greenhouses}

(1)A Greenhouses Business Plan Is systematic evaluation of a venture's chances for success when build new greenhouse tomato and cucumber.way to determine the risks facing a venture greenhouse.plan for managing a business (building greenhouse) successfully.tool for comparing actual and target results . an important tool for attracting capital when start greenhouse projectsCreate new building green house to increase the local product (tomato \& cucumber (Competitive marketing place .(2)Sustainable greenhouse productionStrengths and opportunities for the farmers' households and their community greenhouse who can be involved in this project greenhouse. First a gain in knowledge will be expected. Then when focusing on more than one farmer in a community, this can have a positive influence on knowledge sharing. There will also be a rise in labor demand. This is an opportunity, for example: for unemployed people when strong family ties are absent or when there is not enough labour .(3)Sustainable greenhouse productAvailable with the community.(sulaimani,for bulling greenhouse,2011,p5). This will be prevent an increase in migration andcangive a better and healthier economic situation in the community(Allen Hammer, 2011, p.3).The establishment of a local farmers'organisation can rebuild community feelin,when this was decreasing. These organizations also can be used for othereconomical, developments or problems in greenhouses.(4)Marketing greenhouse (tomato \&cucumber)The marketing greenhouse process includes a range of activitiesintended to identify and satisfy the desires of consumers while earning a profit for the business. These activities include identifying customerneeds,. (]. James C,2010,p.31). developing products and services to meet those needs in the market, establishing promotional programs and pricing for the products and services (tomato \& cucumber), and Implementing a system of distribution to the customers. It is essential to identify and understand the Market and what product consumer need, know who the competition is, and developer market niche. Remember, grow what sells product, notWhat you are fond of. Selling plants (tomato \&cucumber) directly to consumers in a retail business is different from selling plants wholesaleto garden centers or other retail businesses(Allen Hammer, 2011, p32).

\subsubsection{Method of Analysis}

III. Research Methodology

After completion of the questionnaire, raw data were reviewed to make sure that no information was missing before entering it for analytical purposes of the projects cause the data received from the deferent place . In the past, we used a mainframe computer program (Statistical Package for the Social Sciences) to analyze both the individual farm reports as well as computing group averages are used to analyze the greenhouse data. This program is allows changes and updates in many of the cost allocations Each greenhouse operation was analyzed separately .

The study sample was divided by the result that I received in the greenhouses from the project in tanjaro place that I used in my project . In order to preserve confidentiality of the data obtained in the field, no group averages were developed for greenhouse crops with less than three participants. Then Data collected for the 5 year was updated to 2012 crop year by using farm input and prices received for various crop.

\subsubsection{Vision greenhouse:}

Scale farmers will be the best among the farmers in the areas advantage we receives in the nearest few years ,oure main approach is capacity building by training the farmer to have the formation in green houses and participatory on farm-training, benign the future farm ,this is capacity being built for self employment or future management .The farmer greenhouses will gain interims of: High varieties-High returns-Market time and market linkagefood security*rules health standers

\subsubsection{Mission Statement}

Our Mission in greenhouse (tomato and cucumber ) in this project is to lead the industry as the premier grower and marketer of branded, premium quality, greenhouse-grown fresh produce in North America. We constantly strive to exceed our customers' expectations through unparalleled commitment to quality produce and sustainable growing practices in the field.

\subsubsection{What Is the Issue?}

Greenhouse tomato \&cucamberes growers in the Kurdistan are investing in capital-intensive production facilities without a strong base of industry information. Some field tomato \&cucumber in our fields growers are feeling the effects of increased competition but have little information to assess the likely effect on their industry. The issues are contraction in formation. What is the structure of the greenhouse tomato \& cucumber industry? What are the strengths and weaknesses of the various parts of the industry? What is the current level of greenhouse tomato \& cucumber production and how has it grown in Kurdistan? What is the role 
of trade to deal with? How have prices and the dynamic changed with the rapid growth of the industry? What impact has the greenhouse tomato industry had on the fresh field tomato \& cucumber industry?

\section{IV. hypotheses}

We have 150 greenhouses for tomato each green house according to the total revenue in product as the ratio of sulaimani each greenhouse produce (50 ton for each greenhouse tanjaroplace ..for ( febrewary ,march ,April,may,june,julay, august . we sold ech ton by the market price $\$ 500$. quality of the product make the price change according to the roduct in the market place. we got the ( \$375000) for the first grow from February to august . and ( \$ 375000) for the second grow from month ( September) to (January) the total sales price for one years $(\$ 750000)$

Table (2 ) greenhouse tomato product .Table ( 3 ) product cucumber greenhouseses .

\begin{tabular}{|l|}
\hline $\begin{array}{l}\text { TOMATO PRODUCT ( } 5 \text { ton for } \\
\text { each house) }\end{array}$ \\
\hline 5 ton $* 150$ houses \\
\hline 750 \\
\hline \\
\hline 750 \\
\hline
\end{tabular}

\begin{tabular}{|l||}
\hline CUCAMBER PRODUCT (7ton) \\
\hline $7 * 150$ \\
\hline 1050 \\
\hline 1050 \\
\hline \\
\hline 2100 \\
\hline
\end{tabular}

(5)What Did the Study Fin? Total Kurdistan greenhouse tomato production since2007 is estimated at 528,078 metric tons, from field of amounts in the early ( 1300 ) green house in sulaimani. Suleiman is the largest producer with an estimated 42 percent of production, followed by the Kurdish production with 30 percent, and sulaimani according to the study with 28 percent. Was the industry's pioneer and is a market force during its March to December season. The strengths of its industry are high yields and consistent product quality. Volume of summer tomatoes is so great that it is hard for growers in the Unit compete profitably in that season. The main weakness of the kurdistan greenhouse industry is that it does not produce tomatoes in the winter. (Kurdistan, 2011, p52). (6)How Was the Study Conduct Since public data on the greenhouse tomato and cucumber from the field industry are scarce, this analysis rests primarily on extensive interviews with greenhouse and field tomato growers, marketers, and industry representatives in the Kurdistan ,sulaimani. While there are still important data gaps, this study provides the first estimates of production and trade. As the industry grows and government statistics catch up, there will be a firmer basis for analysis to build the future of the .(7)Constraints of greenhouse tomatoes and cucumbers for farmers .We mention some weaknesses and threats for the farmers' households and their communities who will be involved in this project. New tomato and cucumber production system will most likely product in some cultural changes. The agricultural production by greenhouses system is changed and also probably new social networks will arise to market the new product. The presence of one or more greenhouses in the community will also change status and rank(Kurdistan, 2011, p52).

Table (4) : the product of ( tomato \& cucumber ) according to the place of the number of green house project

\begin{tabular}{|c|c|c|c|}
\hline $\begin{array}{l}\text { cucamber production } \\
\text { is } 7 \text { tone for each roon } \\
\text { Y2 }\end{array}$ & \begin{tabular}{l}
\multicolumn{2}{r}{ Tomato production is } \\
5 tone for each \\
GREENHOUSE \\
room \\
Y1
\end{tabular} & $\begin{array}{ll}\text { Number } & \text { of } \quad \text { the } \\
\mathrm{X} & \text { Greenhouse }\end{array}$ & PICE OF THE PROJECT \\
\hline 10600 & 14840 & 2120 & Bzazyan \\
\hline$\overline{4270}$ & 5975 & 854 & Sulaimani \\
\hline 11020 & 15428 & 2204 & Ranya \\
\hline 2355 & 3997 & 471 & Dukan \\
\hline 1705 & 2387 & 341 & Sharazur \\
\hline 525 & 735 & 105 & Chamchamal \\
\hline 380 & 532 & 76 & Kanishaetan \\
\hline 2200 & 3080 & 440 & Germyan \\
\hline 1030 & 1442 & 206 & Saedsadiq \\
\hline 2325 & 3255 & 465 & Halabja \\
\hline 36410 & 50974 & 7282 & sum \\
\hline
\end{tabular}




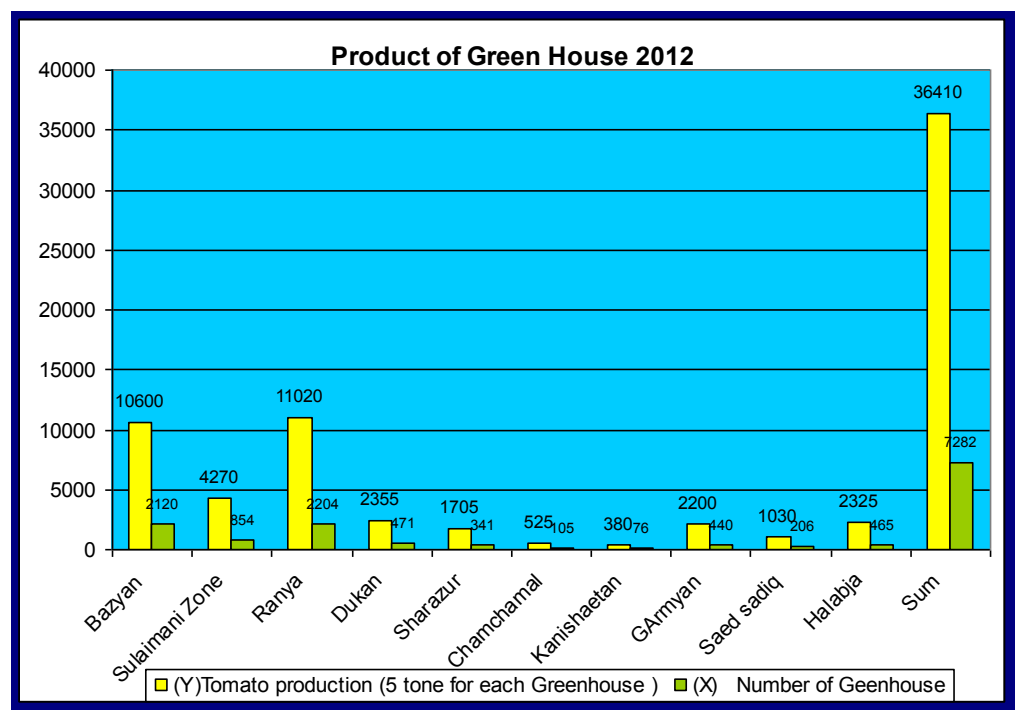

\section{(Advantages of greenhouses)}

\section{Conclution}

(1)the yield may be 10-12 times higher than that of out door cultivation depending upon the type of greenhouse, type of crop, environmental control facilities.

(2)Reliability of greenhouse increases under greenhouse cultivation.

(3)ideally suited for vegetables product (tomato \& cucumber . (

(4)Year round production of tomato and cucumber crops.

(5)Off-season production of vegetable and vegetable crops.

(6)Disease-free and genetically superior transplants can be produced continuously.

(7)Efficient utilisation of chemicals, pesticides to control pest and diseases in the houses.

(8)Water requirement of crops very limited and easy to control during the project.

(9)Maintenance of stock plants, greenhouse cultivating grafted plant-lets and micro propagated plant-lets.

(10)Hardening of tissue cultured plants when the product grown .

(11)Production tomato and cucumber became importantproduct of quality produce free of blemishes.

(12)Most useful in monitoring and controlling the instability of various ecological system by the team direct in the project .

(13)Modern high techniques of Hydroponic (Soil less culture), Aeroponics and Nutrient film techniques are possible only under greenhouse cultivation.

\subsubsection{Recommendation}

[1]- $\quad$ Training courses to the farmer in Kurdistan to produce best product .

[2] Use the wide field for the greenhouse tomato or cucumber to control the cost and expenses.

[3] Build the great number of the greenhouse in the specific place to avoid the delay of the product to the market places.

[4]Advertising the product greenhouses tomato and cucumber to knwn by the people.

[5]Help the company bay giving them loans to make the business greenhouse cause tomato and cucumber have little product in Kurdistan.

[6]Agriculture need to set budget to recommend and supervisor of the greenhouse cause most of the farmer dosent know the scince way to grow thy use the classical way to product .

[7]Cost of the bilding higher the farmer cannot open more greenhouse in one field .

[8]The government must persuade the company to establish moer greenhouse and open most of the project near the city.

[9]Help the local farmer and taught them the new way to produce the deffrent product example produce tomato and cucumber in the winter time.

[10]Scintfic method must offer to the farmer and tech the new worker the way of use medical or the needs of greenhouse cause if make the fult may be spread the diseases .

[11]In the time of the product get the market the government must closes the boarder to help the local product sold.

[12]Most of the lost by the company caused by import the product from Syria and iran with cheper product caused the loss .

[13] Government give the company by ( water , heating, gas system ( To istablish new bulding. 


\section{Acknowledgements}

The author wishes to express sincere thanks to all the greenhouse operators in SULAIMANI CITY - GREENHOUSE DEVELOPMENT - LOLAN GRRN HOUSE COMPAN ) who willingly provided valuable data for this study. in collection of data from greenhouse operators across the province is gratefully acknowledged.

\section{References}

[1] Agriculture Markiting A National Level Quarterly Journal on Agricultural Marketing, Directorate of Marketing\&vInspection Ministry of Agriculture (Deptt. of Agriculture Co-operation) GovernmentofIndia,2005.

[2] Agrculture of sulaimany, Greenhouse Tomatoes, report document,2001.

[3] Agrculture of sulaimany,GreenhouseTomatoes,report document,2001.

[4] Green Production, greenhouse co., 2001.

[5] Allen Hammer Starting a Greenhouse Business, Overview of the Greenhouse Business in Indiana Dept. of Horticulture and Landscape Architecture Purdue University,2011,p.1.

[6]. Allen Hammer,Starting a Greenhouse Business, Architecture,Purdue University,2009.

[7]. Allen Straw, Profitable Greenhouse Production of Local Produce Virginia Cooperative Extension, Greenhouse Vegetable Production, Specialist, SW VA ARE Virginia Cooperative Extension,2001.

[8]. Allen Straw, Profitable Greenhouse Production of Local Produce, Virginia Cooperative Extension, Greenhouse Vegetable Production R. Allen Straw Area Specialist SW VA ARE Virginia Cooperative Extension,2000, ,p65.

[9]. Daniel Danial,PimLindhout,PRODUCTION, Building a future out of tomatoes, 2010.

[10]. Douglas Street, Victoria, B.C., Canada, Preparing A Business Plan: Greenhouse Vegetable Example. 1992. Published by theExtension Systems Branch, British Columbia, Ministry of Agriculture, Fisheries and Food, ,2008.

[11]. Robin G. Brumfield Professor and Extension Specialist RutgersUniversity,Brumfield@aesop.rutgers.edu, Marketing Greenhouse Products,2009.

[12]. Efren fitz.Rodreguez,disition support system, for greentomato production, university of aryzona,,2008.

[13]. Extension Systems Branch, British Columbia, Ministry of Agriculture,,2008.

[14]. G. NabiChaudhary, Economics Branch Economics and Competitiveness Division Alberta Agriculture and Rural Development , September 2011.

[15]. George Hochmuth, A Leading State for Greenhouse Vegetables and Specialty Crops, 2001.

[16]. George W. Dickerson, Greenhouse Vegetable ProductionCircular, , Extension Horticulture Specialist College of Agriculture, Consumer and Environmental SciencesNew Mexico State University,2011.

[17]. Greenhouse company, sulaimani,forbulinggreenhouse,document of geernhouse,2010. Grrenzone company, for establish fiberglass greenhouse in Kurdistan, 2011.

[18]. James Rada, Grants for Starting a Greenhouse Business, 2011.

[19]. James C. Sellmer and Michael N. DanaA National Level Quarterly Journal on Agricultural Marketing, A Farmers Centric Portal on Agricultural Marketing in India and a step towards Globalizing Indian Agriculture,2010.

[20]. Johenmartez - Production and Marketing of Specialty or Novel Vegetables,20011.

[21]. John allen ,Production and Marketing of Specialty or Novel Vegetablesby,2011.

[22]. Liz Maynard,PurdueUniversity,Regulations and Laws, Relating to Greenhouses,2000.,SUST AINABLE GREENHOUSE

[23]. Rob eddyManaging the Greenhouse Environment Temperature, Humidity an Water Plant Growth Facilities Manage Purdue University, HLA Department West Lafayette, IN.2011.

[24]. Manuel Paucar, How to Start a Commercial Organic . Vegetable Greenhouse,2003.

[25]. Maria I.. Marrsha,Ph..D.. Department of Agricultural Economics,2010

[26]. Lolan.co,vegetableproduct,Greenhouse report., 2011

[27]. N. Castilla, Greenhouse Technological Packages For High-Quality Crop Production.2009. co,vegetableproduct,Greenhouse report., 2011

[28]. NabiChaudhary ,Economics Branch Economics and Competitiveness Division Alberta Agriculture and Rural Development, By G., September 2011.

[29]. Paul A. Thomas, starting greenhouse business, , Extension Horticulturist-Floriculture,2001.PREDUZA

[30]. Preparing A Business Plan: Greenhouse Vegetable Example. GREENHOUSE MARKETING, ECONOMICS \& BUSINESS PLANS, 1992. Published by the

[31] Rob Eddy, Managing the Greenhouse Environment Temperature, Humidity an Water Plant Growth Facilities Manage Purdue University, HLA Department,2000.

[32] Roberta Cook and Linda Calvin Greenhouse Tomatoes Change the Dynamics of the North America Fresh Tomato Industry, United States Department of Agriculture, Economic Research Report Number,2011.

[33]. Tanjaro green house, Product of greenhouse, report supervisor, 2001.

[34]. William A. Thomas, Extension Marketing Economist, Cooperative Extension Service The University of Georgia College of Agricultural and Environmental Science Athens,2010.

[35]. Agreculture of Sulaimna, main branch bakrajo, document of greenhouses , 2012. 